\title{
POLA PERILAKU PENCARIAN INFORMASI GENERASI Z BERPERSPEKTIF ELLISIAN
}

\author{
Gustina Erlianti \\ Universitas Negeri Padang \\ e-mail: gustinaerlianti@ fbs.unp.ac.id
}

\begin{abstract}
Abstrak:
Perkembangan teknologi menimbulkan dampak yang besar dalam kehidupan manusia khususnya pada kegiatan pencarian informasi yang semula berbasis tradisional menjadi digital. Tujuan dari penelitian ini adalah untuk mengetahui pola perilaku pencarian informasi generasi Z berperspektif Ellisian. Jenis penelitian adalah kualitatif deskriptif dengan mewawancarai tiga (3) orang informan yang berasal dari mahasiswa angkatan 2018 Program Studi Perpustakaan dan Ilmu Informasi, Universitas Negeri Padang. Dari hasil penelitian dinyatakan bahwa pola perilaku pencarian informasi generasi Z cenderung menggunakan sumber elektronik daripada sumber tercetak. Adapun alasan penggunaan sumber elektronik (google) dalam pencarian informasi adalah mudah dan cepat. Pada saat penelusuran informasi, mereka mencarinya menggunakan kata kunci yang sudah dirancang terkait dengan topik yang dibutuhkan. Untuk merancang kata kunci mereka biasanya tidak menggunakan rujukan atau referensi tetapi berdasarkan pemahaman masing-masing. Setelah melakukan pencarian dengan merawak, informan mengumpulkan semua hasil pencarian dan setelah itu baru di seleksi kembali berdasarkan kevaliditasan dan kebaharuannya. Namun untuk aspek kebaharuan, rata-rata informan sepakat untuk tidak mempertimbangkannya. Berdasarkan hasil penelitian maka rekomendasi ditujukan kepada generasi $\mathrm{Z}$ untuk lebih bijak dalam memilih dan menggunakan informasi terutama yang berasal dari sumber-sumber elektronik dan mempertimbangkan aspek validitas serta kebaharuan sehingga kebutuhan informasinya terpenuhi dengan baik.
\end{abstract}

Kata kunci : generasi Z, kebutuhan informasi, perilaku pencarian informasi, perpustakaan.

\begin{abstract}
:
The development of technology has a great impact on human life, especially on information-gathering activities that were originally based on traditional to digital. The purpose of this study was to determine the pattern of information seeking behavior in the $Z$ generation with Ellisian perspective. This type of research is descriptive qualitative by interviewing three (3) informants from 2018 students of the Library and Information Science, Universitas Negeri Padang. From the results of the study stated that the pattern of information seeking behavior generation $Z$ tends to use electronic sources rather than printed sources. The reason for using electronic sources (google) in information search is easy and fast. When searching for information, they look for it using keywords that have been designed related to the topic needed. To design keywords they usually don't use references or references but are based on their individual understanding. After searching by browsing, the informant collects all the search results and afterwards is re-selected based on validity and renewal. But for the novelty aspect, the average informant agreed not to consider it. Based on the results of the research, recommendations are addressed to Generation $Z$ to be wiser in selecting and using information especially those from electronic sources and considering aspects of validity and novelty so that the information needs are met properly.
\end{abstract}

Keywords : generation Z, information need, information seeking behavior, library 


\section{PENDAHULUAN}

Dewasa ini, kemajuan teknologi yang sangat pesat telah menimbulkan dampak yang besar dalam kehidupan manusia. Dengan memanfaatkan gadget, komputer, laptop, netbook dan perangkat TIK lainnya, manusia dapat saling berkomunikasi dan berbagi informasi dengan cepat tanpa terbatas ruang dan waktu. Hal ini berbanding lurus dengan karakteristik dari generasi $\mathrm{Z}$ yang mana kesehariannya tidak bisa terlepas dari gadget. Menurut Patel (2017), generasi $\mathrm{Z}$ adalah generasi yang dilahirkan pada era teknologi dengan sikap bawaan independen (lebih suka bekerja sendiri daripada bekerjasama/ berkelompok dengan orang lain). ${ }^{1}$ Generasi ini sudah terpaparkan oleh teknologi semenjak usia dini sehingga wajar ketika mereka sangat dekat teknologi/ gadget. Fenomena ini juga diperkuat oleh Fatimah yang menyatakan bahwa pada tahun 2018 saja angka penggunaan gadget/ internet dikalangan remaja mencapai angka 49, 52\%. Angka ini sungguh fantastis mengingat persentase penggunaan yang hampir mencapai $50 \%$ dari masyarakat di Indonesia (Bohang, 2018). ${ }^{2}$ Jadi tidak mengherankan jika perilaku mereka pun berubah mengikuti perkembangan seperti menyelesaikan hampir semua tugas perkuliahan dengan bantuan gadget/ internet.

Terkait dengan fenomena di atas, kemampuan utama yang harus dimiliki generasi $\mathrm{Z}$ yang perannya sebagai penikmat teknologi adalah kemampuan dalam mengelola informasi. Hal ini dapat dianalogikan seperti "siapa yang meguasai informasi berarti dia dapat menguasai dunia". Jadi jelaslah ketika seseorang dapat mengelola informasinya dengan baik maka kualitas

\footnotetext{
1 D Patel. 2017. 8 Ways Generation Z Will Different From Milleials In The Workplace dalam forbes.com

${ }^{2}$ Fatimah Kartini Bohang. 2018. Berapa Jumlah Pengguna Internet Indonesia? dalam kompas.com
}

hidupnya akan menjadi baik pula dan otomatis menjadi pribadi yang cerdas, cekatan serta mudah menempatkan diri dalam berbagai situasi. Secara umum, Ati (2014) menjelaskan informasi ini dapat diartikan sebagai kumpulan fakta dan data yang telah diolah sehingga dapat digunakan dalam pengambilan keputusan.3 Namun dengan pesatnya perkembangan teknologi mengakibatkan banyaknya informasi yang beredar (information overload) sehingga dibutuhkan penyaringan agar informasi yang diterima bisa dipertanggungjawabkan dan dijadikan landasan untuk pengambilan keputusan dikemudian hari. Dalam hal ini, informasi sedikitnya harus memenuhi enam karakter, yaitu luas informasi, kepadatan informasi, jadwal informasi, frekuensi informasi, waktu informasi, dan sumber informasi (Wulandari, 2011). ${ }^{4}$ Karakter ini memang harus diperhatikan dalam kegiatan pencarian informasi karena karakter inilah yang nantinya akan menentukan apakah informasi yang didapat mempunyai nilai guna tinggi atau tidak sehingga dapat memenuhi kebutuhan informasi kita.

Secara umum seseorang cenderung mencari informasi sesuai dengan kebutuhannya. Misal mahasiswa melakukan pencarian informasi untuk membantu menyelesaikan tugas perkuliahan, dokter mencari informasi terkait dengan cara pengobatan terbaru, arsitek mencari informasi terkait dengan desain rumah yang "kekinian" dan lain sebagainya. Dalam pencarian informasi ini pastilah seseorang mempunyai pola tersendiri, termasuk generasi $\mathrm{Z}$ yang cenderung menggunakan caracara praktis dan instan untuk memenuhi kebutuhannya.

Generasi Z memiliki perilaku yang berbeda dengan generasi sebelumnya. Misalnya saja pada Mahasiswa Prodi Perpustakaan dan Ilmu Informasi yang cende-

\footnotetext{
${ }^{3}$ Sri Ati. 2014. Materi Pokok Dasar-Dasar Informasi 1-6. Tanggerang Selatan: Universitas Terbuka. Hal. 1.4

${ }^{4}$ Wulandari. 2011. Materi Pokok Dasar-Dasar Informasi. Jakarta: Universitas Terbuka Hal. 1.6
} 
Almaktabah Vol. 5, No. 1, Juni 2020

rung menggunakan cara-cara praktis dan instan seperti mencarinya di "mbah google" atau sosial media, sehingga tidak terlalu memperhatikan tahapan-tahapan yang tersedia pada model Ellis. Hal ini dibuktikan dengan pengamatan penulis dalam satu tahun terakhir ini, bahwa lebih dari $70 \%$ mahasiswa Prodi Perpustakaan dan Informasi menggunakan referensi dari sumbersumber elektronik. Oleh karena itu, peneliti tertarik untuk melakukan komparasi kebiasaan pencarian informasi generasi $\mathrm{Z}$ tersebut dengan model Ellis sehingga diharapkan memunculkan pola terbaru dari teori sebelumnya.

\section{METODE}

Desain penelitian yang digunakan adalah desain kualitatif deskriptif. Menurut Bogdan dan Taylor dalam Moleong, penelitian kualitatif sebagai prosedur penelitian yang menghasilkan data deskriptif berupa kata-kata tertulis atau lisan dari orang-orang dan perilaku yang dapat diamati (Moleong, 2010). ${ }^{5}$ Senada dengan definisi tersebut Kirk dan Miller dalam Moleong mendefinisikan juga penelitian kualitatif adalah tradisi tertentu dalam ilmu pengetahuan sosial yang secara fundamental bergantung dari pengamatan pada manusia baik dalam kawasannya maupun dalam peristilahnya. Berdasarkan dua pengertian di atas, dapat disimpulkan bahwa penelitian kualitatif adalah penelitian yang bermaksud untuk memahami subjek yang akan diteliti, misal perilaku, persepsi, motivasi, dan tindakan dalam bentuk kata-kata dan bahasa dengan memanfaatkan berbagai metode.

Adapun pendekatan yang digunakan dalam penelitian ini adalah pendekatan deskriptif. Menurut Arikunto (2013), pendekatan ini hanya menggambarkan "apa adanya" tentang suatu variabel, gejala atau keadaan. Pendekatan deskriptif mencoba mencari deskripsi

\footnotetext{
${ }^{5}$ Lexi J. Moleong. 2010. Metodologi Penelitian Kualitatif. Bandung: PT. Remaja Roskakarya
}

yang tepat dan cukup dari semua aktivitas, objek, proses, dan manusia. ${ }^{6}$ Dalam pendekatan deskriptif kualitatif data yang dikumpulkan adalah berupa kata-kata dan gambar bukan angka-angka (Moleong, 2010).

Subjek dalam penelitian ini adalah Tiga (3) orang Mahasiswa Prodi Perpustakaan dan Ilmu Informasi (PII) Universitas Negeri Padang sedangkan objeknya adalah perilaku pencarian informasi Mahasiswa Prodi Perpustakaan dan Ilmu Informasi Universitas Negeri Padang. Pemilihan informan didasarkan pada fenomena yang terjadi saat pemeriksasan tugas akhir mahasiswa Prodi PII di mana referensi yang mereka gunakan sebagian besar bersumber dari sumber-sumber elektronik (google). Dalam penelitian kualitatif, tidak ada patokan untuk jumlah informan sehingga ketika jumlah 1 informan sudah memenuhi asas kesesuaian (appropriateness) bisa langsung digunakan untuk sumber data penelitian (Heryana 2011). ${ }^{7}$ Pemilihan 3 informan ini sudah mumpuni untuk menjadi sumber data karena perilaku populasi cenderung sama (homogen), sehingga bisa dikelompokkan 1 informan sebagai informan kunci, informan pendukung, dan informan pendukung.

Secara keseluruhan teknik analisis data yang dilakukan diawali dengan pengumpulan data dengan cara kajian dokumen dan wawancara, reduksi data dan memilah informasi sesuai dengan tujuan penelitian, serta pengambilan kesimpulan. Adapun untuk validasi data peneliti menggunakan cara trianggulasi. Triangulasi dalam pengujian kredibilitas ini diartikan sebagai pengecekan data dari berbagai sumber dengan berbagai cara, dan berbagai waktu. Dengan demikian terdapat triangulasi sumber, triangulasi teknik pengumpulan data dan triangulasi waktu (Sugiyono, 2013). Dengan meng-

\footnotetext{
${ }^{6}$ Suharsimi Arikunto.2013. Manajemen Penelitian. Jakarta: PT. Asdi Mahasatya

${ }^{7}$ Ade Heryana. Informasi dan Pemilihan Informan dalam Penelitian Kualitatif dalam researchgate.net
} 
gunakan teknik ini, diharapkan menghasilkan data yang valid dan dapat berkontribusi terhadap perkembangan pendidikan. ${ }^{8}$

\section{HASIL DAN DISKUSI}

\section{Hakikat Informasi}

Dalam kehidupan sehari-hari, terdapat banyak makna tentang kata informasi sehingga perlu dibahas lebih lanjut guna memperoleh pemahaman yang sama. Secara umum, informasi dapat diartikan sebagai rekaman fenomena yang diamati, atau bisa juga berupa putusan-putusan yang dibuat (Ati, 2014). Senada dengan ini, Menurut Lasa HS (2009) dalam perspektif perpustakaan informasi dapat diartikan sebagai berita, peristiwa, data, maupun literatur. ${ }^{9}$

Informasi sebagaimana yang telah dibicarakan di atas memiliki tiga kriteria penting yang harus diperhatikan untuk dijadikan pedoman dalam pengambilan keputusan. Kriteria tersebut adalah sebagain berikut (Yusup, 2010):

\section{a. Akurat}

Informasi harus bebas dari kesalahan, dapat digunakan sesuai dengan kebutuhan penggunanya pada situasi tertentu, disajikan secara lengkap pada lingkup yang luas maupun terbatas, menunjukkan kinerja yang maksimal dengan pengukuran aktivitas yang telah diselesaikan sampai kemajuan yang telah dicapai dari sumber daya yang terkumpul.

b. Tepat Waktu

Informasi harus ada saat dibutuhkan, selalu up-todate, dapat disajikan berulangulang sesuai dengan

\footnotetext{
${ }^{8}$ Sugiyono. 2013. Metode Penelitian Kombinasi (Mixed Methods). Bandung: Alfabeta.

${ }^{9}$ Lasa HS. 2009. Kamus Kepustakawanan Indonesia. Yogyakarta: Pustaka Book Publisher
}

kebutuhan, serta dapat disajikan pada periode sekarang, masa lalu, dan masa yang akan datang.

c. Mudah Dimengerti

Informasi harus dapat disajikan dalam bentuk yang mudah dimengerti, dapat disajikan secara detail atau ringkasan, dapat diatur dalam urutan tertentu, dapat disajikan secara naratif baik dalam bentuk angka, grafik dan lainnya, dapat Mudah Dimengerti

Dengan demikian dapat disimpulkan bahwa informasi adalah suatu fakta atau berita yang telah memenuhi kriteria tertentu sehingga dapat menjadi alat untuk membantu pengambilan keputusan saat ini atau di waktu yang akan datang.

\section{Kebutuhan Informasi}

Kebutuhan informasi setiap orang berbeda tergantung latar belakang masing-masing. Misalnya saja guru yang membutuhkan informasi seputar dunia pendidikan akan berbeda dengan dokter yang membutuhkan informasi-informasi medis. Menurut teori Kuhltau, kebutuhan informasi muncul karena adanya gap (kesenjangan informasi) antara informasi yang dimiliki oleh seseorang dan informasi yang dibutuhkannya (Yusup, 2010). Adapun menurut Lasa (2009), kebutuhan informasi yaitu:

"Kebutuhan yang didasarkan pada dorongan untuk memahami, menguasai lingkungan, memuaskan keingin-tahuan/ curiosity, dan penjelajahan/ explorato$r y$. Kemudian informasi diperoleh dari sumber informasi dapat digunakan untuk 1) menambah pengalaman; 2) memperoleh informasi mutakhir; 3) memperoleh pengetahuan sesuai kebutuhan; 4) mengembangkan diri." 10

Jadi dapat disimpulkan bahwa jika ada kesenjangan dalam diri seseorang, maka akan muncul kebutuhan

\footnotetext{
${ }^{10}$ Ibid.
} 
Almaktabah Vol. 5, No. 1, Juni 2020

informasi yang dipengaruhi oleh beberapa faktor antara lain tujuan yang ada dalam diri manusia tersebut. Kesenjangan dalam pikiran seseorang ini disebut dengan situasi problematik atau masalah, sehingga untuk mengatasinya perlu melakukan kegiatan pencarian informasi dengan menggunakan sumber-sumber informasi yang tersedia.

\section{Perilaku Pencarian Informasi Model D. Ellis}

Perilaku pencarian informasi berawal dari adanya kebutuhan seseorang terhadap sesuatu. Pada kondisi ini, seseorang dihadapkan pada situasi problematik yang muncul akibat adanya kesenjangan (anomalous) antara keadaan pengetahuan yang ada di dalam dirinya dengan kenyataan kebutuhan informasi yang diperlukan sehingga menciptakan sebuah proses pencarian informasi yang oleh Belkin dinyatakan sebagai situasi problematik akibat adanya kondisi anomalous state of knowledge dari si pencari informasi (Yusup, 2010). ${ }^{11}$

Perilaku pencarian informasi disebut juga sebagai tindakan yang dilakukan seseorang atau kelompok untuk memenuhi kebutuhan informasinya. Tindakan setiap orang dalam memenuhi kebutuhan informasinya pasti berbeda. Misalnya saja seorang guru yang membutuhkan informasi tentang perkembangan dunia pendidikan sedangkan dokter membutuhkan informasi terkait dengan peralatan dan tindakan medis. Dalam hal ini, Wilson menyatakan bahwa perilaku pencarian informasi adalah :

Information searching behavior is the microlevel of behavior employed by the searcher in interacting with information systems of all kinds. It consists of all the interactions with the system, wheter at the level of human computer interaction (for example, use of the

${ }^{11}$ Pawit M Yusup. Teori da n Praktik Peneusuran Informasi. Jakarta: Kencana. mouse and clicks on links) or at the intellectual level (for exmple, adopting a boolean search strategy or determining the criteria for deciding which of two books selected from adjacent places on a library shelf is most useful), which will also involve mental acts, such as judging the relevance of data or information retrieved. 12

Dari beberapa pendapat di atas dapat disimpulkan bahwa perilaku pencarian informasi merupakan tindakan yang dilakukan untuk mencari, mengumpulkan dan memakai informasi yang dibutuhkan oleh pengguna baik yang berkaitan dengan pekerjaan, tugas, maupun kepentingan pribadi atau kelompok.

Terkait dengan kegiatan di atas, setiap orang pasti mempunyai cara/ strategi tertentu untuk memenuhi kebutuhannya yang biasa dikenal dengan sebutan pola/ model. Pola perilaku pencarian informasi merupakan kerangka ataupun langkah-langkah dalam melakukan pencarian informasi. Pola ini biasanya digambarkan dalam bentuk diagram seperti pola-pola yang dikemukaan oleh Wilson, Krikelas, Johnson, Leckie dan David Ellis.

Pola perilaku pencarian informasi ini dipengaruhi banyak faktor, seperti psikologi, demografi, profesi dan kebutuhan informasi yang dicari. Perbandingan model perilaku pencarian informasi terdapat pada penyebab utama, faktor utama, dan hasil. Perbedaan tiap model diantaranya: model wilson yang menitikberatkan pada kebutuhan dan kondisi seseorang; model krikelas yang berpedoman pada keadaan pencari informasi; model johnson yang disebabkan oleh aspek demografi, peran, pekerjaan; model Leckie yang penyebab utamanya adalah peran kerja dan tugas, serta model Ellis yang penyebab utamanya adalah informasi yang relevan. Dari beberapa model yang tersebut, model Ellis merupakan model yang cocok karena karakter dari ge-

\footnotetext{
${ }^{12}$ Ibid.
} 
nerasi $\mathrm{Z}$ yang cenderung mencari informasi terkini dan relevan dengan kehidupannya.

Model Ellis ini tercipta ketika ia mengembangkan teorinya dengan mengadakan penelitian kegiatan sehari-hari yang dilakukan oleh objeknya, seperti mencari bacaan, meneliti di laboratorium, menulis makalah, mengajar dan sebagainya. Hasil penelitian Ellis adalah pola pencarian yang terdiri dari enam tahap pencarian informasi, yaitu starting, chaining, browsing, differentiating, monitoring and extracting (Yusup, 2010). Ellis menegaskan bahwa 6 (enam) ini saling berkaitan untuk membentuk aneka pola pencarian informasi dan seringkali bukan tahapan-tahapan yang teratur. Enam kelompok kegiatan pencarian adalah sebagai berikut.

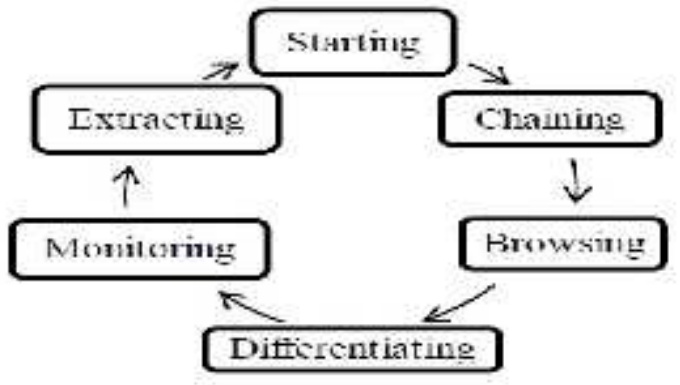

Gambar 1

Model Ellis

\section{Generasi Z}

Perkembangan teknologi yang sangat cepat ternyata juga berdampak pada perubahan komposisi penduduk yang otomatis menyebabkan perubahan pula pada pola perilakunya. Kondisi ini ditandai dengan menurunnya kelompok baby boomers (kelompok kelahiran 1946-1960), dan meningkatnya kemompok usia produktif (generasi Y dan Z) sehingga pola perilaku yang semua berbasis konvensional berubah menjadi serba digital (menggunakan bantuan teknologi).

Generasi $\mathrm{Z}$ adalah golongan yang dilahirkan tahun 1995 hingga 2010 yang disebut juga dengan generasi teknologi. Menurut penelitian Bencsik, Csikos, dan
Juhez (2016), masuknya Generasi Z didalam kelompok generasi, dapat dilihat melalui tabel berikut. ${ }^{13}$

\section{Tabel 1}

Perbedaan Generasi

\begin{tabular}{|l|l|l|}
\hline NO & Tahun Generasi & Nama Generasi \\
\hline 1. & $1925-1946$ & Veteran Generation \\
\hline 2. & $1946-1960$ & Baby boom generation \\
\hline 3. & $1960-1980$ & X generation \\
\hline 4. & $1980-1995$ & Y generation \\
\hline 5. & $1995-2010$ & Z generation \\
\hline 6. & $2010^{+}$ & Alfa generation \\
\hline
\end{tabular}

Enam kelompok generasi tersebut memiliki karakteristik yang berbeda-beda. Generasi paling muda yang baru memasuki angkatan kerja adalah generasi Z/ iGeneration/ generasi internet. Generasi Z memiliki kesamaan dengan generasi $\mathrm{Y}$, namun terdapat sedikit perbedaan di mana generasi $\mathrm{Z}$ lebih multitasking dibandingkan generasi Y. Misalnya saja mereka bisa mengaplikasikan semua pekerjaan dalam satu waktu seperti menjalankan sosial media, browsing menggunakan PC, mengetik, mendengarkan musik menggunakan headset. Apapun yang dilakukan kebanyakan berhubungan dengan dunia maya sehingga akan mempengaruhi pola perilakunya dalam kehidupan sehari-hari.

Fenomena ini juga didukung oleh hasil studi peneliti dari Fakultas Psikologi Universitas Padjadjaran, yang menyatakan bahwa keragaan generasi $\mathrm{Z}$ di Indonesia berdasarkan beberapa aspek, yaitu (Hinduan 2017): ${ }^{14}$

a. Berdasarkan jenis gadgetnya

\footnotetext{
${ }^{13}$ Bencsik, A., Csikos, G., \& Juhaz, T. 2016. Y and Z Generations at Workplaces dalam Jurnal of Competitveness.

${ }^{14}$ Hinduan, Z.r., M.I. Agia, dan S. Kholiq. (2017). Generation Z in Indonesia: Psychological Capital, Work Value, and Learning Style. Universitas Padjadjaran.
} 
Almaktabah Vol. 5, No. 1, Juni 2020

Sebanyak 99\% memiliki smartphones, 66\% memiliki notebook (bahkan beberapa di antaranya lebih dari 1 buah), $42 \%$ memiliki komputer pribadi, $36 \%$ memiliki tablet, dan 15\% memiliki laptop;

b. Jenis media sosial yang digunakannya

Semua siswa yang disurvei (100\%) memiliki akun Line, 97\% memiliki akun WhatsApp, 91\% memiliki akun Facebook, 98\% memiliki akun Instagram, 82\% memiliki akun Path, dan $78 \%$ memiliki akun Twitter. Sebanyak $12 \%$ memiliki akun LinkedIn, dan menggunakan Telegram sebanyak 20\%;

c. Berdasarkan penggunaan gadgetnya

Pada umumnya, gadget mereka pergunakan untuk media sosial (98\%), akademik (93,5\%), nonton film $(85 \%)$, email (84\%), main games (74\%), dan pesan barang daring $(68 \%)$

Melihat persentase di atas terlihat jelas bahwa perilaku generasi berbanding lurus dengan perkembangan teknologi yang mempengaruhi semua aspek kehidupan termasuk aspek pendidikan. Di sinilah perguruan tinggi dituntut untuk mampu mengikuti perkembangan yang ada dengan merancang dan menyelenggarakan pembelajaran secara kreatif dan inovatif untuk meningkatkan mutu pendidikan di kampus.

\section{Hasil Penelitian}

Berdasarkan hasil wawancara dengan 3 informan, perilaku pencarian informasi generasi $\mathrm{Z}$ dengan mengacu pada teori D. Ellis sebagai berikut.

\section{Starting}

Starting adalah kegiatan-kegiatan yang biasanya dilakukan seorang pengguna informasi saat pertama kali mencari tahu tentang suatu bahasan tertentu dengan melakukan overview terhadap literatur-literatur yang ada dalam suatu bidang atau mencari tahu orang-orang yang ahli dalam suatu bidang tertentu.
Pada tahap ini penulis menanyakan beberapa hal kepada informan mengenai tahap awal yang dilakukan ketika membutuhkan informasi. Mereka melakukan pencarian informasi ini dilatarbelakangi oleh tugastugas yang diberikan oleh dosennya. Ketiga informan ini sepakat hal pertama yang dilakukan adalah mencari informasi tersebut dari sumber-sumber elektronik (google) dengan alasan mudah dan cepat. Namun informan kedua menambahkan selain mencari melalui sumber elektronik, ia juga mendiskusikan topik yang dicari dengan teman atau dosen.

\section{Chaining}

Chaining adalah mengikuti rangkaian kutipankutipan atau mengikuti rangkaian hubungan-hubungan referensial antar bahan informasi. Pada tahap ini, informan cenderung membuat kata kunci terlebih dahulu untuk memperkecil hasil pencarian di sumber elektronik. Dalam menentukan kata kunci, mereka tidak merujuk pada referensi-referensi tertentu, tetapi hanya menggunakan pemahaman masing-masing.

\section{Browsing}

Browsing merupakan pencarian semi terarah pada wilayah dari bahasan yang lebih spesifik yang diminati. Aktivitas yang termasuk dalam kelompok kegiatan ini adalah seperti menelusur daftar isi sebuah jurnal atau menelusur jajaran buku dengan tema tertentu di rak buku perpustakaan.

Pada tahap ini informan menginputkan kata kunci yang telah diperoleh pada tahap chaining menggunakan browser google, kemudian melakukan proses merawak sesuai dengan kebutuhan. Setelah itu mereka mengumpulkan semua hasil pencariannya. Adapun pencarian terhadap sumber tercetak, para informan jarang menggunakannya karena sulit menemukan dan membutuhkan waktu yang lama.

\section{Differentiating}


Differentiating adalah kegiatan memilah dan memilih bahasan sumber informasi berdasarkan derajat kepentingan dan ketepatan serta relevansinya dengan kebutuhan infomasi, sehingga terpilih bahan sumber informasi yang paling tepat dan paling relevan.

Pada tahap ini, 2 informan sepakat memilih informasi hanya sesuai dengan kebutuhan tanpa memperhatikan kevalidan dan kepakaran penulis. Namun informan ke-3 menyatakan dalam memilih, ia memperhatikan kepakaran penulis dan kevaliditasannya.

\section{Monitoring}

Monitoring adalah memantau perkembangan terakhir mengenai pokok bahasan yang menjadi fokus penelitian, adalah salah satu fitur perilaku pencarian informasi yang dilakukan oleh para ilmuwan ilmu sosial.

Pada tahap ini informan telah menemukan informasi yang dicarinya, tiga informan sepakat tidak mencari pembaharuan terhadap hasil pencariannya, orientasi mereka hanyalah pada kecocokan tugas dengan informasi yang diperoleh.

\section{Extracting}

Extracting adalah mengidentifikasi secara selektif bahan sumber informasi yang telah didapat untuk mendapatkan informasi yang diminati. Pada tahap ini sseseorang melakukan pengecekan kembali terhadap informasi yang telah dipilih yang akan digunakan untuk menyelesaikan tugasnya.

Pada tahap ini, hanya satu informan yang melakukannya, mengingat pola generasi "zaman now" yang cenderung pola perilakunya yang serba instan dan cepat.

\section{KESIMPULAN}

Berdasarkan hasil wawancara pada pembahasan, maka dapat disimpulkan bahwa secara keseluruhan dari informan sepakat melakukan kegiatan pencarian informasi ketika mendapatkan tugas dari dosennya. Dalam melakukan proses pencarian informasi, mereka cenderung menggunakan sumber elektronik daripada sumber tercetak. Adapun alasan penggunaan sumber elektronik (google) dalam pencarian informasi adalah mudah dan cepat sehingga ketika dibandingkan dengan sumber tercetak, mereka harus ke perpustakaan dulu jika koleksi buku di rumah tidak mencukupi.

Pada saat penelusuran informasi, informan mencarinya menggunakan kata kunci yang sudah dirancang terkait dengan topik yang dibutuhkan. Untuk merancang kata kunci mereka biasanya tidak menggunakan rujukan atau referensi tetapi berdasarkan pemahaman masing-masing. Setelah melakukan pencarian dengan merawak, informan mengumpulkan semua hasil pencarian dan setelah itu baru di seleksi kembali berdasarkan kevaliditasan dan kebaharuannya. Namun para informan tidak terlalu mempertimbangkannya terutama untuk kebaharuan informasi.

\section{REFERENSI}

Arikunto, S. (2013). Manajemen Penelitian. Jakarta: PT. Asdi Mahasatya.

Ati, S. (2014). Materi Pokok Dasar-Dasar Informasi 16. Tanggerang Selatan. Universitas Terbuka.

Bencsik, A., Csikos, G., \& Juhaz, T. (2016). Y and Z Generations at Workplaces. Journal of Competitiveness, 8(3), 90-106. https://doi.org/10.7441/joc.2016.03.06

Bohang, F. K. (2018, 2 22). Berapa Jumlah Pengguna Internet Indonesia? Retrieved 07 29, 2019, from KOM-

PAS.com:https://tekno.kompas.com/read/2018/0 2/22/16453177/berapa-jumlah-penggunainternetindonesia 
Almaktabah Vol. 5, No. 1, Juni 2020

Heryana, Ade. (2011). Informasi dan Pemilihan Informan dalam Penelitian Kualitatif. Universitas Esa Unggul:

https://www.researchgate.net/profile/Ade H eryana2/publication/329351816 Informan dan Pemili-

han_Informan dalam Penelitian_Kualitatif/ links/5c02c716299bf1a3c159bd92/Informan -dan-Pemilihan-Informan-dalam-PenelitianKualitatif.pdf

Hinduan, Z.r., M.I. Agia, dan S. Kholiq. (2017). Generation $\mathrm{Z}$ in Indonesia: Psychological Capital, Work Value, and Learning Style. Universitas Padjadjaran.

Lasa Hs. (2009). Kamus Kepustakawanan Indonesia. Yogyakarta: Pustaka Book Publisher.

Moleong, L.J. (2010). Metodologi Penelitian Kualitatif. Bandung: PT. Remaja Rosdakarya.

Patel, D. (2017). 8 Ways Generation Z Will Different From Millennials In The Workplace: https://www.forbes.com/sites/deeppatel/2017/09/ 21/8-ways-generation-z-will-differfrommillennials-in-theworkplace/\#34bc140b76e5.

Sugiyono. (2013). Metode Penelitian Kombinasi (Mixed Methods). Bandung: Alfabeta.

Wulandari. (2011). Materi Pokok Dasar-Dasar Informasi. Jakarta: Universitas Terbuka.

Yusup, P. dan Subekti. P. (2010). Teori dan Praktik Penelusuran Informasi. Jakarta: Kencana. 